\title{
PROBABILITY OF FAILURE \\ OF THE TRUDOCK CRANE SYSTEM AT THE \\ WASTE ISOLATION PILOT PLANT (WIPP)
}

\author{
Moses A. Greenfield, Ph.D \\ Consultant to Environmental Evaluation Group \\ Professor Emeritus, University of California, Los Angeles
}

Thomas J. Sargent, Ph.D.

Professor of Economics, Stanford University

Senior Fellow, Hoover Institution

Environmental Evaluation Group 7007 Wyoming Blvd., NE, Suite F-2

Albuquerque, New Mexico 87109

and

505 North Main Street, P.O. Box 3149

Carlsbad, New Mexico 88221-3149

May 2000 



\section{DISCLAIMER}

Portions of this document may be illegible in electronic image products. Images are produced from the best available original document. 


\section{DISCLAIMER}

This report was prepared as an account of work sponsored by an agency of the United States Government. Neither the United States Government nor any agency thereof, nor any of their employees, make any warranty, express or implied, or assumes any legal liability or responsibility for the accuracy, completeness, or usefulness of any information, apparatus, product, or process disclosed, or represents that its use would not infringe privately owned rights. Reference herein to any specific commercial product, process, or service by trade name, trademark, manufacturer, or otherwise does not necessarily constitute or imply its endorsement, recommendation, or favoring by the United States Government or any agency thereof. The views and opinions of authors expressed herein do not necessarily state or reflect those of the United States Government or any agency thereof. 


\section{FOREWORD}

The purpose of the New Mexico Environmental Evaluation Group (EEG) is to conduct an independent technical evaluation of the Waste Isolation Pilot Plant (WIPP) Project to ensure the protection of the public health and safety and the environment. The WIPP Project, located in southeastern New Mexico, became operational in March 1999 for the disposal of transuranic (TRU) radioactive wastes generated by the national defense programs. The EEG was established in 1978 with funds provided by the U. S. Department of Energy (DOE) to the State of New Mexico. Public Law 100-456, the National Defense Authorization Act, Fiscal Year 1989, Section 1433, assigned EEG to the New Mexico Institute of Mining and Technology and continued the original contract DE-AC04-79AL10752 through DOE contract DE-ACO489AL58309. The National Defense Authorization Act for Fiscal Year 1994, Public Law 103160, and the National Defense Authorization Act for Fiscal Year 2000, Public Law 106-65, continued the authorization.

EEG performs independent technical analyses of the suitability of the proposed site; the design of the repository, its planned operation, and its long-term integrity; suitability and safety of the transportation systems; suitability of the Waste Acceptance Criteria and the compliance of the generator sites with them; and related subjects. These analyses include assessments of reports issued by the DOE and its contractors, other federal agencies and organizations, as they relate to the potential health, safety and environmental impacts from WIPP. Another important function of EEG is the independent environmental monitoring of background radioactivity in air, water, and soil, both on-site and off-site.

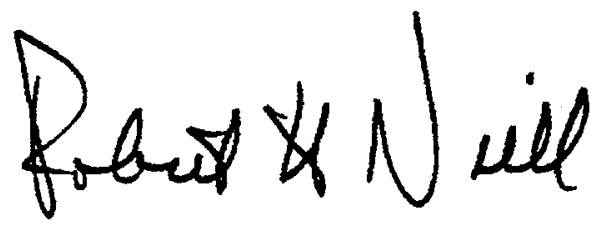

Robert H. Neill

Director 


\section{EEG STAFF}

Sally C. Ballard, B.S., Radiochemical Analyst

William T. Bartlett, Ph.D., Health Physicist

Radene Bradley, Secretary III

James K. Channell, Ph.D., Environmental Engineer/Health Physicist

Lokesh Chaturvedi, Ph.D., Deputy Director \& Engineering Geologist

Patricia D. Fairchild, Secretary III

Donald H. Gray, M.A., Laboratory Manager

Linda P. Kennedy, M.L.S., Librarian

Jim W. Kenney, M.S., Environmental Scientist/Supervisor

Lanny W. King, Assistant Environmental Technician

Robert H. Neill, M.S., Director

Dale Rucker, M.S., Environmental Engineer

Jill Shortencarier, Executive Assistant

Matthew K. Silva, Ph.D., Chemical Engineer

Susan Stokum, Administrative Secretary

Ben A. Walker, B.A., Quality Assurance Specialist

Brenda J. West, B.A., Administrative Officer 


\section{ACKNOWLEDGMENTS}

The authors wish to thank Jill Shortencarier for expert preparation of the manuscript. We thank our colleague Dale Rucker for helpful reviews and suggestions, and for contributing basic information. We also thank our colleague Robert $\mathrm{H}$. Neill for helpful suggestions. The authors are also grateful to their colleagues at EEG (James K. Channell, Lokesh Chaturvedi, Ben Walker, William Bartlett) for reviews and suggestions. Special thanks are due to Matthew Silva for a valuable addition. We also thank Linda Kennedy for her expertise in improving the report and its references. 
vi 


\section{TABLE OF CONTENTS}

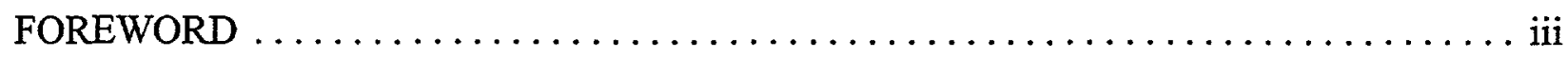

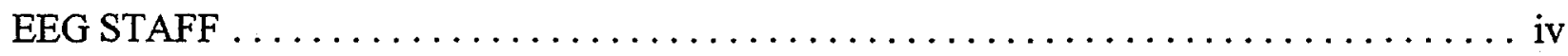

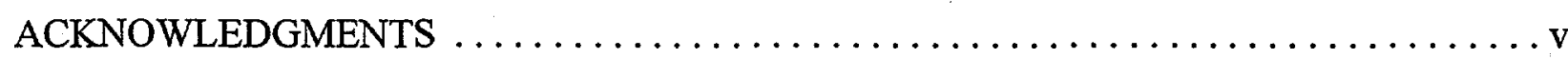

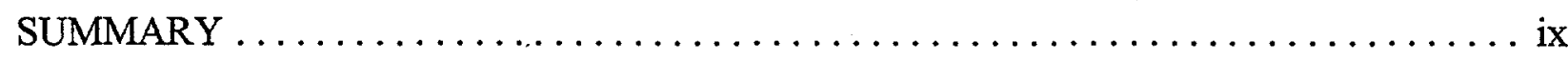

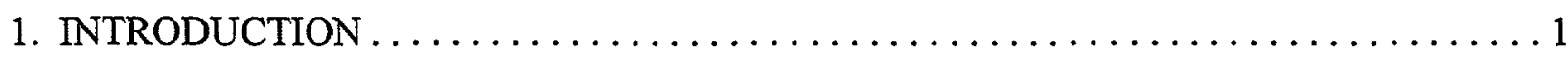

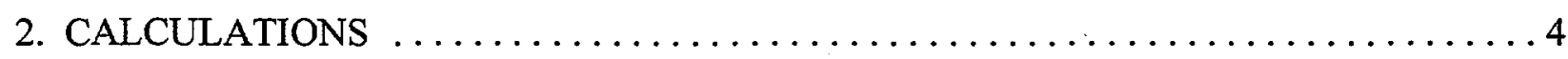

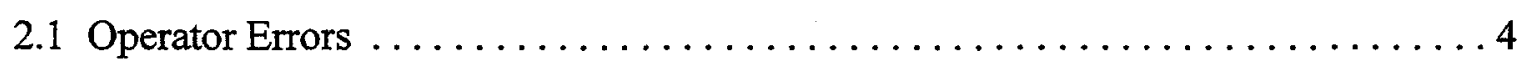

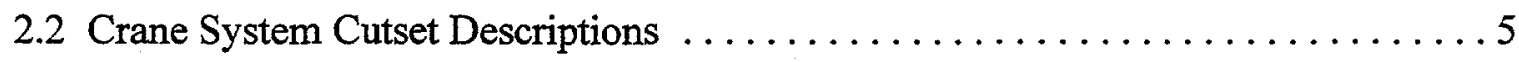

2.3 Use of Confidence Levels . . . . . . . . . . . . . . . . . . . . . 6

2.4 Lognormal Calculations $\ldots \ldots \ldots \ldots \ldots \ldots \ldots \ldots \ldots \ldots \ldots \ldots$

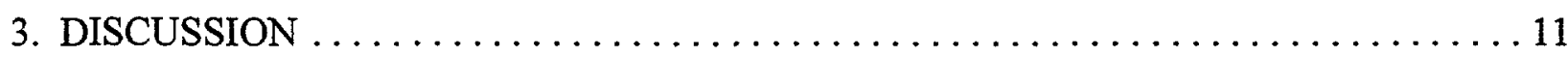

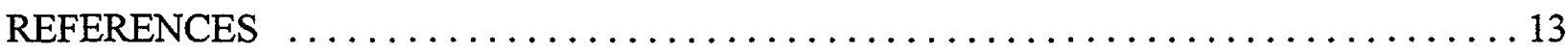

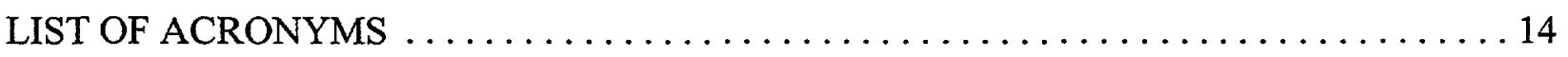

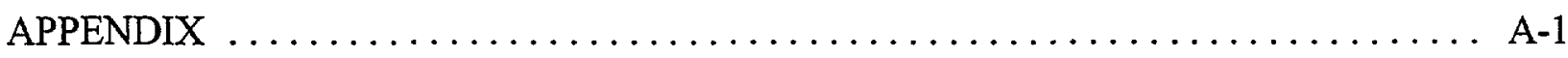

LIST OF EEG REPORTS $\ldots \ldots \ldots \ldots \ldots \ldots \ldots \ldots \ldots \ldots \ldots \ldots \ldots \ldots \ldots \ldots \ldots \ldots \ldots \ldots$ 


\section{LIST OF TABLES}

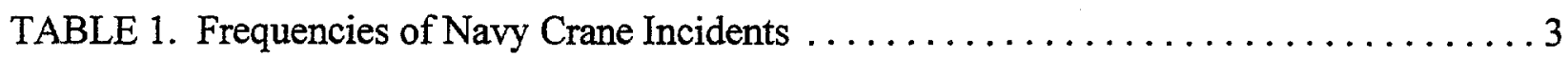

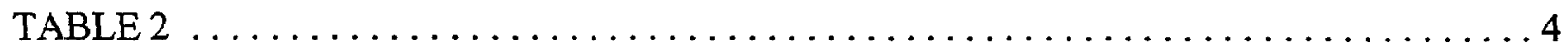

TABLE 3. Cutset Probabilities .....................................

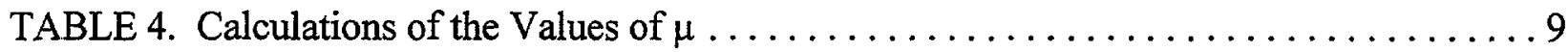

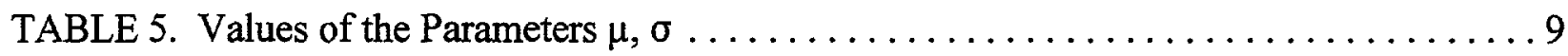

TABLE 6. Percentiles and Probability Values of the Grand Total of the Four

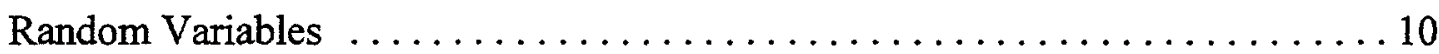

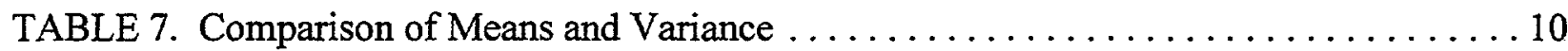

\section{LIST OF FIGURES}

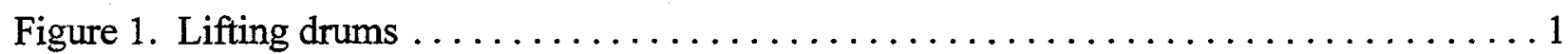

Figure 2. Cumulative distribution function for probability of failure of the TRUDOCK crane system 


\section{SUMMARY}

This probabilistic analysis of WIPP TRUDOCK crane failure is based on two sources of failure data. The source for operator errors is the report by Swain and Guttman, NUREG/CR-1278-F, August 1983. The source for crane cable hook breaks was initially made by WIPP/WID-962196, Rev. 0 by using relatively old (1970s) U.S. Navy data (NUREG-0612). However, a helpful analysis by R.K. Deremer of PLG guided the authors to values that were more realistic and more conservative, with the recommendation that the crane cable/hook failure rate should be $2.5 \times 10^{-6}$ per demand. This value was adopted and used.

Based on these choices a mean failure rate of $9.70 \times 10^{-3}(1 / \mathrm{yr})$ was calculated. However, a mean rate by itself does not reveal the level of confidence to be associated with this number. Guidance to making confidence calculations came from the report by Swain and Guttman, who stated that failure data could be described by lognormal distributions. This is in agreement with the widely used reports (by DOE and others) NPRD-95 and NPRD-91, on failure data.

The calculations of confidence levels showed that the mean failure rate of $9.70 \times 10^{-3}(1 / \mathrm{yr})$ corresponded to a percentile value of approximately 71 ; i.e. there is a $71 \%$ likelihood that the failure rate is less than $9.70 \times 10^{-3}(1 / \mathrm{yr})$. One also calculated that there is a $95 \%$ likelihood that the failure rate is less than $29.6 \times 10^{-3}(1 / \mathrm{yr})$. Or, as stated previously, there is a $71 \%$ likelihood that not more than one dropped load will occur in 103 years. Also, there is a $95 \%$ likelihood that not more than one dropped load will occur in approximately 34 years.

It is the responsibility of DOE to select the confidence level at which it desires to operate. 


\section{PROBABILITY OF FAILURE OF THE TRUDOCK CRANE SYSTEM AT THE WASTE ISOLATION PILOT PLANT (WIPP)}

\section{INTRODUCTION}

In March 1999, the Department of Energy began emplacing transuranic waste into the Waste Isolation Pilot Plant (WIPP). The facility is located in southeast New Mexico in bedded salt at a depth of 650 meters. The repository is designed to contain 176,000 cubic meters $(850,000$ drum equivalents) of contact-handled transuranic (CH TRU) waste and 7,100 cubic meters $(8,000$ canisters) of remote handled transuranic (RH TRU) waste. The contact handled waste will be shipped from various defense generator and storage sites throughout the nation in an NRC certified container called a TRUPACT II or in a shorter version called a HALFPACK. In preparation for shipping, fourteen drums of waste, two standard waste boxes, or eight overpack drums are lowered into each TRUPACT-II. An inner lid and an outer lid secure the top of the shipping container.

Upon arrival at the WIPP, the drums or boxes need to be unloaded from the shipping container. This will be done in the Waste Handling Building where there are two TRUDOCK cranes. The two cranes are six-ton overhead bridge cranes, and are capable of operating alone or in parallel. To unload each shipping container, the outer lid needs to be lifted ( $3520 \mathrm{lbs}$.) and the inner lid needs to be lifted $(895 \mathrm{lbs}$.). Each is set to the side. Figure 1 shows that two seven drum arrays can be lifted and handled as a single unit. The lift is over two meters and the payload can weigh as much as 7,265 lbs. Assuming at least three lifting operations for each TRUPACT there would be 182,000 lifting operations to unload 850,000 drum equivalents of CH TRU waste or about 5200 lifting operations per year (1500 crane transfers/year x 3 lifts/TRUPACT-II) for the

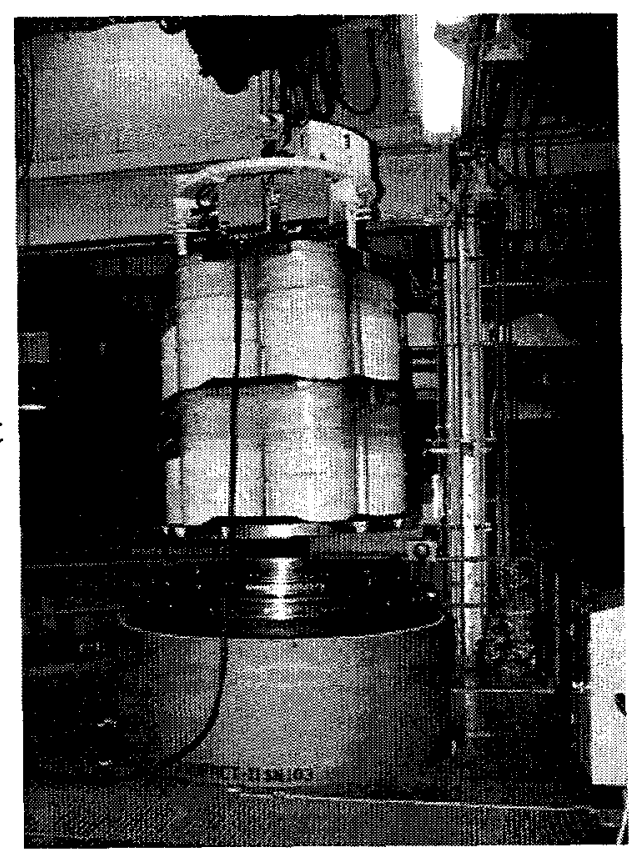

Figure 1. Lifting drums. 35 year operational life of the facility. 
The DOE report, WIPP-WID-96-2196, Rev. 0, published in October 1996, studies and evaluates the possible frequency of failure of the TRUDOCK crane system, resulting in a dropped load and the loss of the drums' containment. The report turned to NUREG-0612 (July 1980) for failure data based on experience with U.S. Navy cranes in the 1970s.

However, the authors of WIPP-WID-96-2196, Rev. 0, 10/25/96, apparently had some concerns about using the data directly from NUREG-0612. The authors evidently turned for help to an independent source, Mr. R. Kenneth Deremer of PLG, an engineering consulting firm. Mr. Deremer's report is contained as Appendix A5 in WID-96-2196. According to Deremer's report, a preliminary version of the DOE report listed a failure "rate" of " $2.0 \mathrm{E}(-5)$ per demand for crane cable/hook failures and cites NUREG-0612 as the basis for this value". Mr. Deremer is critical of that value, and then proceeded to his evaluation of a more realistic and more conservative value and he states that, "the crane cable/hook failure rate should be less than approximately 2.5E(-6) per demand"; that is a reduction of almost a factor of 10 . Mr. Deremer makes the point that the NUREG-0612 data were compiled in the 1970s; and he states that the operating environment at WIPP is much less demanding than those for Navy cranes. He also mentions the aggressive inspection and maintenance programs at WIPP, "to assure the continuing reliability of the cranes". He believes that the failure rates could even be lowered, but states that "it is difficult to quantify this additional improvement".

In his summary Mr. Deremer strongly restates his recommendation of a choice in the data base for the crane cable/hook contribution "of the order of $2.5 \mathrm{E}(-6)$ per demand". Mr. Deremer's recommendation was adopted by the authors of WIPP-WID-96-2196. In the key table of that report, on the Crane System Cutset Descriptions, page A2-5, the Event Probability for the Crane Cable/Hook Breaks is listed as 2.5E(-6).

Support for the critical view by Mr. Deremer of the operating experience of Navy cranes may be seen by noting the relative frequencies of equipment failures vs. operator failures reported in "Navy Crane Incidents" (reports obtained from the U.S. Navy), for the recent years 1996, 1997 and 1998 (Table 1). The number of incidents associated with operator failure is an astonishing 90 to $95 \%$. 
TABLE 1

Frequencies of Navy Crane Incidents

\begin{tabular}{|l|l|l|l|}
\hline Year & \multicolumn{1}{|c|}{1998} & \multicolumn{1}{c|}{1997} & \multicolumn{1}{c|}{1996} \\
\hline Total no. of incidents & 196 & 167 & 154 \\
\hline No. due to equipment failure/percentage & $11 / 5.6 \%$ & $16 / 9.6 \%$ & $7 / 4.6 \%$ \\
\hline No. due to operator failure/percentage & $185 / 94.4 \%$ & $151 / 90.4 \%$ & $147 / 95.4 \%$ \\
\hline
\end{tabular}

Another source of information of hoisting and rigging incidents comes from a recent report by the Office of Oversight, U.S. Department of Energy, Washington, DC, 20585. The report is "Independent Oversight Special Study of Hoisting and Rigging Incidents within the Department of Energy", October 1996. The report covers a 30 month interval, from October 1, 1993 to March 31, 1996. The report states that "Human error is the major cause of hoisting and rigging incidents" (page 8).

This is similar to the data in the "Navy Crane Incidents" reports, with major causes of incidents due to operator rather than equipment failures.

In sharp contrast, in WIPP-WID-96-2196, for WIPP crane system experience, the operators are not the major cause of incidents. As the report states, "Crane operators and load spotters are required to be trained in safe crane operation; therefore it is felt that the WIPP crane performance will exceed the data presented in NUREG-0612, and the estimated failure frequency is felt to be conservative." 


\section{CALCUlations}

\subsection{Operator Errors}

Operator errors are described in the table on page A4-6, of WIPP-WID-96-2196, Rev. 0. For convenience this table is reproduced (as Table 2) in this report, with some additions.

TABLE 2

\begin{tabular}{|c|c|c|c|c|}
\hline Symbol & HEP & Explanation of Error & Source of HEP & Page* \\
\hline$A_{1}$ & $3.7 \times 10^{-3}$ & $\begin{array}{l}\text { Improperly mate a connector, including failure to test the } \\
\text { locking feature for engagement }\end{array}$ & Table 20-12.* Item (13), mean value. & $20-28$ \\
\hline $\mathrm{B}_{1}$ & 0.75 & $\begin{array}{l}\text { The operator repeating the action is modeled to have a } \\
\text { high dependency for making the same error again. It is not } \\
\text { complete dependence, because the operator moves to the } \\
\text { second lifting leg and must physically push the locking } \\
\text { balls to insert the pins. }\end{array}$ & $\begin{array}{l}\text { Table } 20-21 .^{*} \text { Item (4)(a), high } \\
\text { dependence for different pins. Two } \\
\text { opportunities (the second and third } \\
\text { pins) to repeat error is modeled as } \\
0.5+(1-0.5) * 0.5=0.75 \text {. }\end{array}$ & $20-37$ \\
\hline $\mathrm{C}_{1}$ & $1.2 \times 10^{-3}$ & $\begin{array}{l}\text { Checker fails to verify the proper insertion of the } \\
\text { connector pins, and that status affects safety when } \\
\text { performing tasks. }\end{array}$ & Table 20-22.* Item (9), mean value. & $20-38$ \\
\hline$D_{1}$ & 0.15 & $\begin{array}{l}\text { Checker fails to verify the proper insertion of the } \\
\text { connector pins at a later step, given the initial failure to } \\
\text { recognize the error. Sufficient separation in time and } \\
\text { additional cues to warrant moderate rather than total or } \\
\text { high dependence. }\end{array}$ & $\begin{array}{l}\text { Table } 20-21 .^{*} \text { Item }(3)(\text { a), moderate } \\
\text { dependence for second check. }\end{array}$ & $20-37$ \\
\hline$F_{1}$ & $4.99 \times 10^{-7}$ & Failure rate if first pin improperly connected. & Product of above HEPs. & \\
\hline$a_{1}$ & 0.996 & Given the first pin was properly connected. & $1-F_{1}$ & \\
\hline $\mathrm{A}_{2}$ & $3.7 \times 10^{-3}$ & $\begin{array}{l}\text { Improperly mate a connector, including failure to test the } \\
\text { locking feature for engagement. }\end{array}$ & Table 20-12.* Item (13), mean value. & $20-28$ \\
\hline $\mathbf{B}_{2}$ & 0.5 & $\begin{array}{l}\text { The operator repeating the action is modeled to have a } \\
\text { high dependency for making the same error again. It is not } \\
\text { complete dependence, because the operator moves to the } \\
\text { second lifting leg and must physically push the locking } \\
\text { balls to insert pins. }\end{array}$ & $\begin{array}{l}\text { Table } 20-21 .^{*} \text { Item (4)(a), high } \\
\text { dependence for different pins. Only } \\
\text { one opportunity for error (the third } \\
\text { pin). }\end{array}$ & $20-37$ \\
\hline $\mathrm{C}_{2}$ & $1.2 \times 10^{-3}$ & $\begin{array}{l}\text { Checker fails to verify the proper insertion of the } \\
\text { connector pins, and that status affects safety when } \\
\text { performing tasks. }\end{array}$ & Table 20-22.* Item (9), mean value. & $20-38$ \\
\hline $\mathrm{D}_{2}$ & 0.15 & $\begin{array}{l}\text { Checker fails to verify the proper insertion of the } \\
\text { connector pins at a later step, given the initial failure to } \\
\text { recognize the error. Sufficient separation in time and } \\
\text { additional cues to warrant moderate rather than total or } \\
\text { high dependence. }\end{array}$ & $\begin{array}{l}\text { Table } 20-21 .^{*} \text { Item }(3)(a), \text { moderate } \\
\text { dependence for second check. }\end{array}$ & $20-37$ \\
\hline $\mathrm{F}_{2}$ & $3.32 \times 10^{-7}$ & Failure rate if first pin improperly connected. & Product of above HEPs. & \\
\hline$F_{T}$ & $8.31 \times 10^{-7}$ & Total failure rate due to human error. & $F_{1}+F_{2}$ & \\
\hline
\end{tabular}

* HEP stands for Human Error Probability.

* The source of the data is in a report by Swain and Guttman, "Handbook of Human Reliability Analysis with Emphasis on Nuclear Power Plant Applications", August 1983, NUREG/CR-1278-F. 


\subsection{Crane System Cutset Descriptions}

The table in page A2-5 of the WIPP-WID-96-2196 report lists all the basic events that can contribute to crane failures, including crane cable hook breaks, disk brake actuator failures, crane motor failures, etc., in addition to the operator errors. The calculations of the "cutset probabilities" (chances of failing) are given in detail. Of the thirteen listed cutset probabilities, only the first four need to be considered, since the remaining nine are orders of magnitude smaller.

Table 3 is an abbreviation of the table in page A2-5, and it lists the four contributing components to the cutset probabilities. Note that the failure rate for a crane cable hook break is listed as 2.50 $\times 10^{-6}$ (1/demand), the value recommended by Mr. Deremer. The mean failure rate, per demand, due to operator error, is $8.31 \times 10^{-7}$ (see in Table 3). As indicated in Table 3, the reduced sum of the probability of failure is $9.70 \times 10^{-3}(1 / \mathrm{yr})$, or approximately, one failure every 103 years.

TABLE 3

Cutset Probabilities

\begin{tabular}{|c|c|c|c|c|c|c|c|}
\hline & $\begin{array}{l}\text { Cutset } \\
\text { Number }\end{array}$ & Ref. & Page & Failure Mode & $\begin{array}{l}\text { Failure Rate } \\
\text { mean, per } \\
\text { demand }\end{array}$ & $\begin{array}{l}\text { Number Crane } \\
\text { Transfers/yr } \\
\text { App. } A_{2}, A_{2-3}\end{array}$ & $\begin{array}{l}\text { Event Prob. } \\
\text { (cutset } \\
\text { prob.) }\end{array}$ \\
\hline \multirow{2}{*}{$\begin{array}{l}\text { Equipment } \\
\text { Failure }\end{array}$} & 1 & $\begin{array}{l}\text { Appendix } \\
\mathrm{A}_{5} \\
\end{array}$ & 3 & $\begin{array}{l}\text { Crane B cable } \\
\text { hook breaks }\end{array}$ & $2.50 \times 10^{-6}$ & $1.456 \times 10^{3}$ & $3.64 \times 10^{-3}$ \\
\hline & 2 & $\begin{array}{l}\text { Appendix } \\
\mathrm{A}_{5}\end{array}$ & 3 & $\begin{array}{l}\text { Crane A cable } \\
\text { hook breaks }\end{array}$ & $2.50 \times 10^{-6}$ & $1.456 \times 10^{3}$ & $3.64 \times 10^{-3}$ \\
\hline \multirow{2}{*}{$\begin{array}{l}\text { Operator } \\
\text { Error }\end{array}$} & 3 & $\begin{array}{l}\text { Table } 2 \\
\text { (this } \\
\text { report) }\end{array}$ & & $\begin{array}{l}\text { Improper } \\
\text { connection due } \\
\text { to Operator } \\
\text { Error* }\end{array}$ & $8.31 \times 10^{-7}$ & $\begin{array}{l}1.456 \times 10^{3} \\
\text { (Crane B) }\end{array}$ & $1.21 \times 10^{-3}$ \\
\hline & 4 & $\begin{array}{l}\text { Table } 2 \\
\text { (this } \\
\text { report) }\end{array}$ & & $\begin{array}{l}\text { Improper } \\
\text { connection due } \\
\text { to Operator } \\
\text { Error* }\end{array}$ & $8.31 \times 10^{-7}$ & $\begin{array}{l}\text { (Crane A) } \\
1.456 \times 10^{3}\end{array}$ & $1.21 \times 10^{-3}$ \\
\hline & & $P=\sum_{1}^{4}$ & & $\begin{array}{l}=9.70 \times 10^{-3}( \\
\text { tely one failur }\end{array}$ & $\begin{array}{l}\text { bability of } \\
\text { ery } 103 \text { ye }\end{array}$ & lure & \\
\hline
\end{tabular}

*Note that the contribution of Operator Error is only about $25 \%$ of the total. 


\subsection{Use of Confidence Levels}

The calculation in Table 3 of the probability of failure doesn't tell the whole story. One also wishes to know the confidence level that is associated with the failure rate of $9.70 \times 10^{-3}(1 / \mathrm{yr})$. It is helpful to follow the recommendations of the Nuclear Regulatory Commission to include mean estimates and to "take into account the potential uncertainties that exist so that an estimate can be made on the confidence level to be ascribed to the quantitative results." This quotation is taken from the Nuclear Regulatory Commission (NRC 1986). EEG makes the same recommendation, and a calculation of confidence levels is made in this report.

A suggestion of the distribution of HEPs (see Table 2) is made by Swain and Guttman (NUREG/CR-1278-F, page 7-1, page 2-18) to use lognormal distributions. Another helpful source on this matter are the reports NPRD-91 and the more recent NPRD-95, by Denson, Chandler, Crowell, Clark and Jaworski, 1994, "Nonelectronic Parts Reliability Data." Both reports NPRD-91 and NPRD-95 have been used as sources of failure data by DOE in their recent reports: WIPP/WID-96-2178, Rev. 0, July 1996 and WCAP-13800, February 1994 (Preliminary Draft Report).

Both NPRD-91 and NPRD-95 state that all listed failure rates "estimate" the expected failure rates, and that the "true" values lie in some confidence intervals about these estimates. The following statement is a quote from NPRD-91 (Denson et al. 1991), page 1-6:

"To give NPRD-91 users a better understanding of the confidence they can place in the presented failure rates, an analysis was performed on the variation in observed failure rates. It was concluded that, for a given generic part type, the natural logarithm of the observed failure rate is normally distributed with a sigma $(\sigma)=1.5$. This indicates that 68 percent of actual failure rates will be between 0.22 and 4.5 times the mean value. Similarly, $90 \%$ of actual failure rates will be between 0.08 and 11.9 times the presented value." 
This is to state that if one wishes to include $90 \%$ of all the failure rates, one must include a range of values that somewhat exceeds two orders of magnitude $\left(\frac{11.9}{0.08}=148\right)$. Under these circumstances, representing the failure rate by a mean value alone disregards relevant information. 


\subsection{Lognormal Calculations}

A general form for the lognormal distribution with the two parameters, $\mu, \sigma$ is given by (Aitchison and Brown, 1969):

$$
d \Lambda(x)=\frac{1}{(x \sigma \sqrt{2 \pi})} \exp \left\{-\frac{1}{\left(2 \sigma^{2}\right)}(\log x-\mu)^{2}\right\} d x
$$

where $\Lambda$ is the cumulative distribution function (CDF).

The median of the distribution is given by:

$$
x_{m d}=e^{\mu}
$$

The mean is given by: $x_{m n}=e^{\mu+\left(\frac{1}{2}\right) \sigma^{2}}$

According to the NPRDs (Denson et al., 1991, 1994) $\sigma$ is taken as equal to 1.5 .

from (2): $\mu=\ln \left[e^{-\left(\frac{1}{2}\right) \sigma^{2}} \cdot x_{m n}\right]$

since $\sigma=1.5 ; e^{-\left(\frac{1}{2}\right) \sigma^{2}}=e^{-1.125}=0.3247$

thus: $\mu=\ln \left[0.3247 \cdot x_{m n}\right]$

The values of (EP), the Cutset Event Probabilities, are listed in the right most column of Table 3. Let $\mathrm{x}_{\mathrm{mn}}=10^{3} \cdot(\mathrm{EP})$; the values of $\mathrm{x}_{\mathrm{mm}}$ are listed in Table 4 . 
TABLE 4

Calculations of the Values of $\mu$

\begin{tabular}{|c|c|c|c|}
\hline $\begin{array}{c}\text { Cutset } \\
\text { Number }\end{array}$ & $x_{m n}=10^{3} \cdot(E P)=e^{\mu+\frac{1}{2} \sigma^{2}}$ & $\begin{array}{c}\text { (From Equation 3) } \\
e^{\mu}=\left(0.3247 x_{m n}\right)\end{array}$ & $\mu$ \\
\hline 1 & 3.64 & 1.1819 & 0.1671 \\
\hline 2 & 3.64 & 1.1819 & 0.1671 \\
\hline 3 & 1.21 & 0.3929 & -0.9342 \\
\hline 4 & 1.21 & 0.3929 & -0.9342 \\
\hline
\end{tabular}

Table 4 can be summarized as follows:

TABLE 5

Values of the Parameters $\mu, \sigma$

\begin{tabular}{|c|c|c|}
\hline$P_{i}$ & $\mu_{i}$ & $\sigma_{i}$ \\
\hline 1 & 0.1671 & 1.5 \\
\hline 2 & 0.1671 & 1.5 \\
\hline 3 & -0.9342 & 1.5 \\
\hline 4 & -0.9342 & 1.5 \\
\hline
\end{tabular}

The failure distribution, $\mathrm{P}$, can be expressed as follows:

$$
\begin{gathered}
\mathrm{P}=10^{-3} \sum_{i=1}^{i=4} \mathrm{P}_{\mathrm{i}} \\
d \mathrm{P}_{\mathrm{i}}(x)=\frac{1}{\left(x \sigma_{i} \sqrt{2 \pi}\right)} \exp \left[-\frac{1}{\left(2 \sigma_{i}^{2}\right)}\left(\log x-\mu_{i}\right)^{2}\right] d x
\end{gathered}
$$

The failure distribution, $P$, has been expressed as the sum of four lognormal random variables, $P_{i}$. The factor $10^{-3}$ is introduced to cancel the $10^{+3}$ used in the columns of Table 4 . The methods used to compute the failure distribution functions are described in detail in the Appendix. 
Table 6 lists the percentile values for the approximating probability distribution of the grand total of the four random variables.

TABLE 6

Percentiles and Probability Values of the Grand

Total of the Four Random Variables

\begin{tabular}{|c|c|}
\hline Percentile & Probability $\times 10^{3}(1 / \mathrm{yr})$ \\
\hline 0.5 & 0.65 \\
1. & 0.8 \\
5. & 1.4 \\
10. & 1.85 \\
20. & 2.8 \\
50. & 5.8 \\
Mean $=71$ & 9.70 \\
80 & 12.8 \\
90 & 20. \\
95 & 29.6 \\
99 & 65.5 \\
99.5 & 89.5 \\
\hline
\end{tabular}

TABLE 7

Comparison of Means and Variance

True Mean

9.701

Approximating Mean

9.698

True Variance

249.83

Approximating Variance

246.51

For the grand total of the four random variables the approximating and true means and variance are listed in Table 7 without the factor $\left(10^{-3}\right)$. The values of the approximations are close to the true values. This indicates that the approximations for the probability values listed in Table 6 have relatively small errors. 


\section{DISCUSSION}

The data in Table 6 for the probability and the percentiles have been plotted on "probability-log" graph paper; see Figure 2. Some statements may be made, based on Figure 2 or Table 6 .

(a) The mean failure rate is $9.70 \times 10^{-3}(1 / \mathrm{yr})$, and corresponds to a percentile value of approximately 71 , i.e. there is a $71 \%$ likelihood that the failure rate is less than $9.70 \times 10^{-3}(1 / \mathrm{yr})$.

(b) At the 95 percentile, the probability is slightly less than $30 \times 10^{-3}(1 / \mathrm{yr})$ (actually 29.6 from Table 6); i.e. there is a $95 \%$ likelihood that the failure rate is less than $29.6 \times 10^{-3}(1 / \mathrm{yr})$.

(c) The above statements may be recast in another way:

There is a $71 \%$ likelihood that not more than one dropped load will occur in 103 years. Also, there is a $95 \%$ likelihood that not more than one dropped load will occur in approximately 34 years. One may calculate the corresponding time intervals for lower and higher levels of likelihood. Which level of likelihood does one select? That choice is the responsibility of DOE to make. 


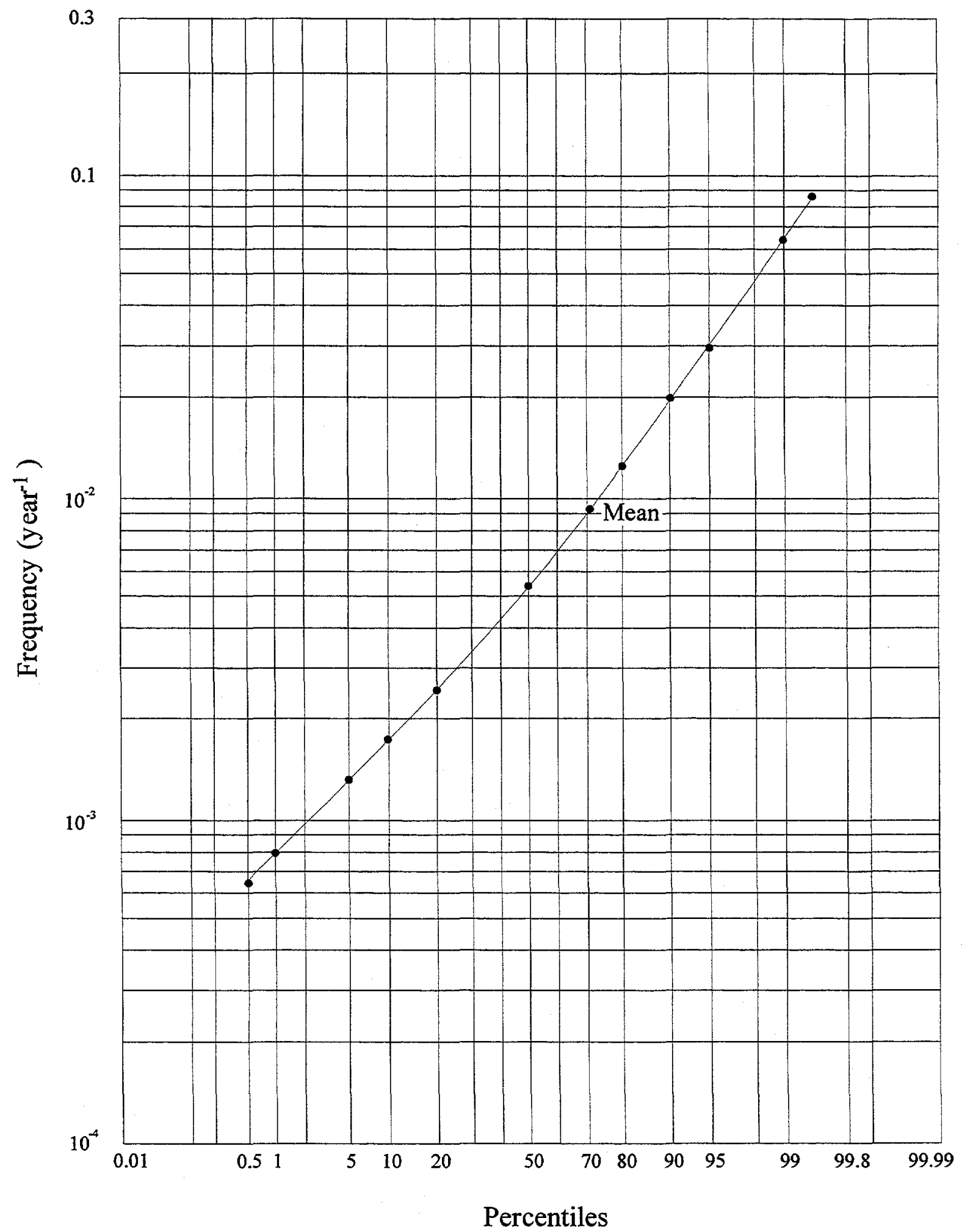

Figure 2. Cumulative distribution function for probability of failure of the TRUDOCK crane system 


\section{REFERENCES}

Aitchison, J. and Brown, J.A.C., 1969. The lognormal distribution. Cambridge University Press, NY, NY.

Denson, W., Chandler, G., Crowell, W. and Wanner, R., 1991. Nonelectric Parts Reliability Data. NPRD-91, Griffis A.F.B., NY.

Denson, W., Chandler, G., Crowell, W., Clark, A. and Jaworski, P., 1994. Nonelectronic Parts Reliability Data. NPRD -95, Griffis, A.F.B., NY.

Nuclear Regulatory Commission, 10 CFR 50. "Safety Goals for the Operation of Nuclear Power Plants, Policy Statement, Correction and Republication." Federal Register 51, No. 162, 21 August 1986, p. 30028-30033.

Nuclear Regulatory Commission, "Control of Heavy Loads at Nuclear Power Plants," NUREG0612 , July 1980.

Swain, A.D. and Guttman, H.E., 1983. Handbook of Human Reliability Analysis with Emphasis on Nuclear Power Plant Applications. NUREG/CR-1278-F, U.S. Nuclear Regulatory Commission.

U.S. Department of Energy. Office of Environment, Safety and Health. Office of Oversight. Independent Oversight Special Study of Hoisting and Rigging Incidents within the Department of Energy. Washington, D.C., October 1996. <http://www.tishq.eh.doe.gov/oversight/reviews/hoist_rig.html>. (Accessed April 12, 2000).

Westinghouse Electric Corporation, Waste Isolation Division, 1996. Waste Isolation Pilot Plant, Trudock Crane System Analysis. WIPP/WID-96-2196, Rev. 0.

Westinghouse Electric Corporation, Waste Isolation Division, 1994. Waste Isolation Pilot Plant, Waste Hoist Brake System Analysis (preliminary draft report). WCAP-13800, Westinghouse Electric Corporation. 


\section{LIST OF ACRONYMS}

$\begin{array}{ll}\text { EEG } & \text { Environmental Evaluation Group } \\ \text { EP } & \text { Event Probabilities } \\ \text { NPRD } & \text { Nonelectronic Parts Reliability Data } \\ \text { NRC } & \text { Nuclear Regulatory Commission } \\ \text { DOE } & \text { United States Department of Energy } \\ \text { WID } & \text { Waste Isolation Division } \\ \text { WIPP } & \text { Waste Isolation Pilot Plant }\end{array}$




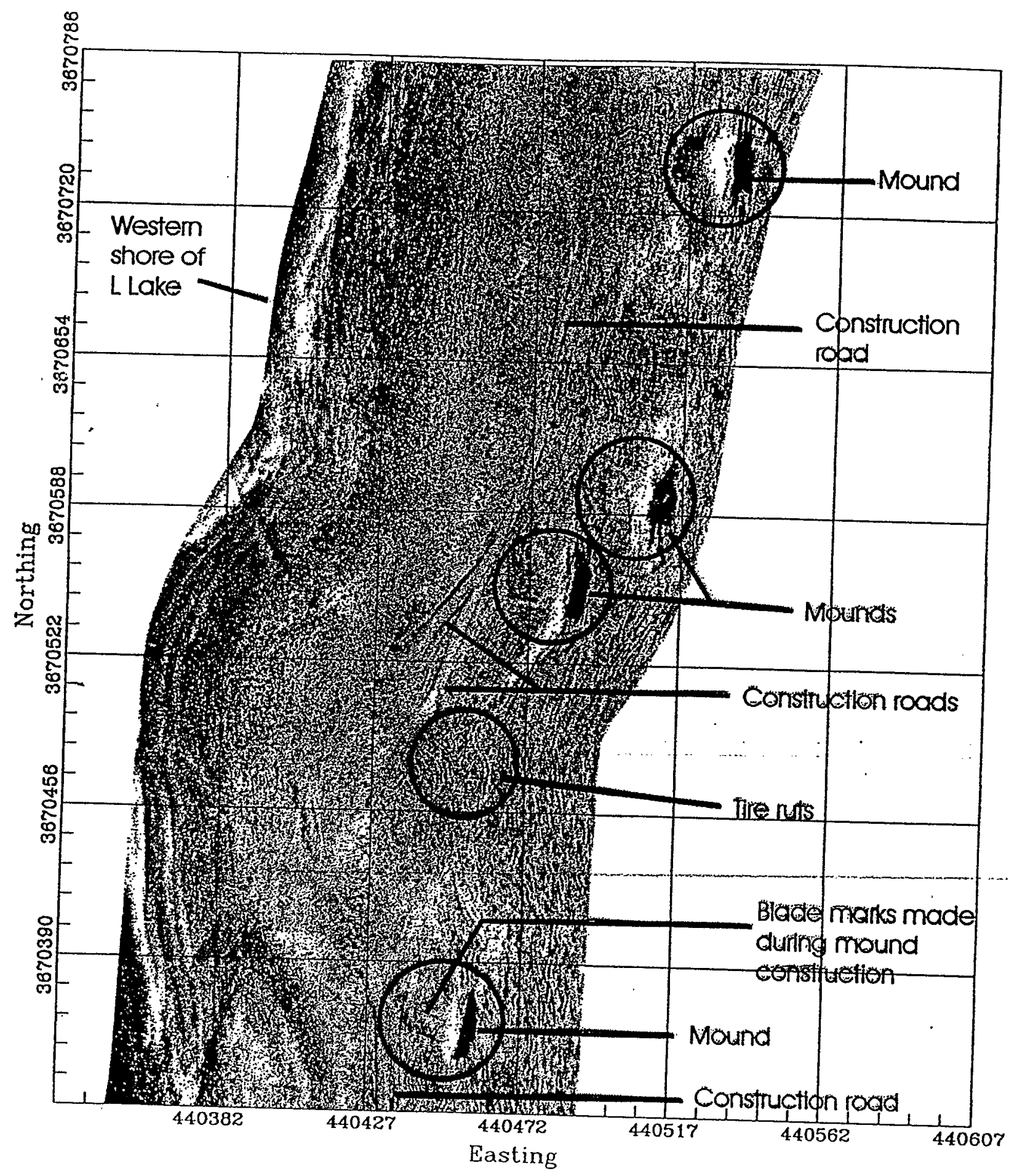

Figure 17. Sonar images of at least four mounds along survey line SL06. A number of construction roads are also visible. 


\begin{abstract}
APPENDIX
This appendix describes how we numerically approximated the density of the random variable $x=\sum_{i=1}^{4} x_{i}$, where each $x_{i}$ is distributed independently of $x_{j}, j \neq i$ and is log normal with parameters $\mu_{i}, \sigma_{i}$. The distribution of a sum of two independent random variables is the convolution of the two distributions. But convolution in the time domain corresponds to multiplication in the frequency domain. This allows us to compute the distribution that we want by taking the Fourier transform of each density, multiplying them, and then inverse Fourier transforming.
\end{abstract}

\title{
Transform Methods
}

We want to compute the density function for a random variable that is the sum of two independently distributed random variables with known densities. ${ }^{1}$ We use the following theorem:

Theorem: Let $x$ be a continuously distributed random variable with density $f(x)$, and let $y$ be a continuously distributed random variable with density $g(y)$. Let $x$ and $y$ be independently distributed. Then the random variable $z=x+y$ is distributed with density $h(z)$ given by the convolution of $f$ and $g$, which is defined by

$$
h(z)=\int f(u) g(z-u) d u
$$

A related theorem governs discrete approximations to continuously distributed random variables.

${ }^{1}$ The mathematical theorems can be found in many books on operational mathematics. For example, see R.A. Gabel and R.A. Roberts, Signals and Linear Systems, Wiley, 1973. 
Theorem: Let $x$ be a random variable that takes values on the set $X=\left[x_{0}, x_{1}, \ldots, x_{T-1}\right]$, with density $f_{t}=\operatorname{Prob}\left[x=x_{t}\right]$. Let $y$ be another random variable that takes values on the same set $X$, with density $g_{t}=\operatorname{Prob}\left[y=x_{t}\right]$. Let $z$ be the random variable $z=x+y$, and let $x$ and $y$ be distributed independently. Then $z$ has density $h$ with

$$
h_{t}=\sum_{k} f_{k} g_{t-k}
$$

where $h_{t}=\operatorname{Prob}\left[z=z_{t}\right]$, and where $z$ resides in the discrete set $Z=\left[2 x_{\theta}, \ldots, 2 x_{T-1}\right]$.

The next useful result is that the Fourier transform of a convolution is the product of the Fourier transforms of the two sequences being convoluted. The Fourier transform of a sequence $\left\{x_{t}\right\}_{t=0}^{t=T-1}$ is defined as the sequence of complex numbers $x\left(\omega_{j}\right)$ given by

$$
x\left(\omega_{j}\right)=\sum_{t=0}^{T-1} x_{i} e^{-i \omega_{j} t}
$$

where $\omega_{j}=2 \pi j / T$ and $j=0,1, \ldots, T-1$. The inverse Fourier transform is given by

$$
x_{t}=T^{-1} \sum_{j=0}^{T-1} x\left(\omega_{j}\right) e^{i \omega_{j} t}
$$

Equations (1) and (2) constitute the basic Fourier transform pair. Notice that the inverse Fourier transform of the Fourier transform is the original sequence.

The key theorem for us is:

Theorem: The Fourier transform of the convolution of two sequences $\left\{x_{t}\right\}$ and $\left\{y_{t}\right\}$ is the product of their Fourier transforms $x\left(\omega_{j}\right) y\left(\omega_{j}\right)$. 
We apply this theorem as follows. For each of two continuous distributions, $(f, g)$, the probability laws for $(x, y)$, respectively, we put down a discrete 'grid' of points $X=\left[x_{0}, \ldots, x_{T-1}\right]$ on the real line, with the points spaced close enough together and over a sufficiently large set to approximate each continuous distribution well. Then we used $(f, g)$ to generate approximating discrete probability distributions for $(x, y)$. For computational consistency, we used the same grid for each random variable under study. We chose the grid carefully to make sure that each random variable as well as the relevant sums were well approximated by the procedure. For each approximating distribution $\hat{f}_{t}$ and $\hat{g}_{t}$, we computed the Fourier transform $f\left(\omega_{j}\right)$ and $g\left(\omega_{j}\right)$. Then we computed the Fourier transform of $\left\{\hat{h}_{t}\right\}$, the approximating distribution of the sum $x+y$, as

$$
h\left(\omega_{j}\right)=f\left(\omega_{j}\right) g\left(\omega_{j}\right)
$$

To compute the approximate density of $x+y, \hat{h}_{t}$, we then inverse Fourier transformed $h\left(\omega_{\mathrm{j}}\right)$ :

$$
\hat{h}_{t}=T^{-1} \sum_{t=0}^{T-1} h\left(\omega_{j}\right) e^{i \omega_{j} t}
$$

\section{Computational Details}

We implemented these calculations using the Fast Fourier Transform (FFT) and the associated inverse transform, the IFFT. We used the computer language MATLAB on a Dell $450 \mathrm{MHz}$ PC with $128 \times 3 \mathrm{~K}$ of memory. This permitted us to put down very large and fine grids. We used one (inconsequential) approximation: each time a convolution is computed, the FFT in effect truncates the grid on which the relevant sum is distributed, and restricts it to the same domain on which the original two distributions are defined. In particular, the density of the sum is computed only on the same domain $X=\left[x_{0}, x_{1}, \ldots, x_{T-1}\right]$, rather than on the true domain $Z=$ $\left[2 x_{0}, \ldots, 2 x_{T-1}\right]$. To control the error resulting from this approximation, we select the grid set $X$ very carefully to make sure that it covers the region where the pertinent $x, y$, and sum $z=x+y$ have appreciable positive probability. 


\section{LIST OF EEG REPORTS}




\section{LIST OF EEG REPORTS}

EEG-1 Goad, Donna, A Compilation of Site Selection Criteria Considerations and Concerns Appearing in the Literature on the Deep Disposal of Radioactive Wastes, June 1979.

EEG-2 Review Comments on Geological Characterization Report. Waste Isolation Pilot Plant (WIPP) Site, Southeastern New Mexico SAND 78-1596. Volume I and II, December 1978.

EEG-3 Neill, Robert H., James K. Channell, Carla Wofsy, Moses A. Greenfield (eds.) Radiological Health Review of the Draft Environmental Impact Statement (DOE/EIS-0026-D) Waste Isolation Pilot Plant. U.S. Department of Energy, August 1979.

EEG-4 Little, Marshall S., Review Comments on the Report of the Steering Committee on Waste Acceptance Criteria for the Waste Isolation Pilot Plant, February 1980.

EEG-5 Channell, James K., Calculated Radiation Doses From Deposition of Material Released in Hypothetical Transportation Accidents Involving WIPP-Related Radioactive Wastes, October 1980.

EEG-6 Geotechnical Considerations for Radiological Hazard Assessment of WIPP. A Report of a Meeting Held on January 17-18, 1980, April 1980.

EEG-7 Chaturvedi, Lokesh, WIPP Site and Vicinity Geological Field Trip. A Report of a Field Trip to the Proposed Waste Isolation Pilot Plant Project in Southeastern New Mexico. June 16 to 18, 1980, October 1980 .

EEG-8 Wofsy, Carla, The Significance of Certain Rustler Aquifer Parameters for Predicting LongTerm Radiation Doses from WIPP, September 1980.

EEG-9 Spiegler, Peter, An Approach to Calculating Upper Bounds on Maximum Individual Doses From the Use of Contaminated Well Water Following a WIPP Repository Breach, September 1981.

EEG-10 Radiological Health Review of the Final Environmental Impact Statement (DOE/EIS-0026) Waste Isolation Pilot Plant. U. S. Department of Energy, January 1981.

EEG-11 Channell, James K., Calculated Radiation Doses From Radionuclides Brought to the Surface if Future Drilling Intercepts the WIPP Repository and Pressurized Brine, January 1982.

EEG-12 Little, Marshall S., Potential Release Scenario and Radiological Consequence Evaluation of Mineral Resources at WIPP, May 1982.

EEG-13 Spiegler, Peter, Analysis of the Potential Formation of a Breccia Chimney Beneath the WIPP Repository, May 1982.

EEG-14 Not published.

EEG-15 Bard, Stephen T., Estimated Radiation Doses Resulting if an Exploratorv Borehole Penetrates a Pressurized Brine Reservoir Assumed to Exist Below the WIPP Repository Horizon - A Single Hole Scenario, March 1982. 


\section{LIST OF EEG REPORTS (CONTINUED)}

EEG-16 Radionuclide Release, Transport and Consequence Modeling for WIPP. A Report of a Workshop Held on September 16-17, 1981, February 1982.

EEG-17 Spiegler, Peter, Hydrologic Analyses of Two Brine Encounters in the Vicinity of the Waste Isolation Pilot Plant (WIPP) Site, December 1982.

EEG-18 Spiegler, Peter and Dave Updegraff, Origin of the Brines Near WIPP from the Drill Holes ERDA-6 and WIPP-12 Based on Stable Isotope Concentration of Hydrogen and Oxygen, March 1983.

EEG-19 Channell, James K., Review Comments on Environmental Analysis Cost Reduction Proposals (WIPP/DOE-136) July 1982, November 1982.

EEG-20 Baca, Thomas E., An Evaluation of the Non-Radiological Environmental Problems Relating to the WIPP, February 1983.

EEG-21 Faith, Stuart, Peter Spiegler, Kenneth R. Rehfeldt, The Geochemistry of Two Pressurized Brines From the Castile Formation in the Vicinity of the Waste Isolation Pilot Plant (WIPP) Site, April 1983.

EEG-22 EEG Review Comments on the Geotechnical Reports Provided by DOE to EEG Under the Stipulated Agreement Through March 1, 1983, April 1983.

EEG-23 Neill, Robert H., James K. Channell, Lokesh Chaturvedi, Marshall S. Little, Kenneth Rehfeldt, Peter Spiegler, Evaluation of the Suitability of the WIPP Site, May 1983.

EEG-24 Neill, Robert H. and James K. Channell, Potential Problems From Shipment of High-Curie Content Contact-Handled Transuranic (CH-TRU) Waste to WIPP, August 1983.

EEG-25 Chaturvedi, Lokesh, Occurrence of Gases in the Salado Formation, March 1984.

EEG-26 Spiegler, Peter, Proposed Preoperational Environmental Monitoring Program for WIPP, November 1984.

EEG-27 Rehfeldt, Kenneth, Sensitivity Analysis of Solute Transport in Fractures and Determination of Anisotropy Within the Culebra Dolomite, September 1984.

EEG-28 Knowles, H. B., Radiation Shielding in the Hot Cell Facility at the Waste Isolation Pilot Plant: A Review, November 1984.

EEG-29 Little, Marshall S., Evaluation of the Safety Analysis Report for the Waste Isolation Pilot Plant Project, May 1985.

EEG-30 Dougherty, Frank, Tenera Corporation, Evaluation of the Waste Isolation Pilot Plant Classification of Systems. Structures and Components, July 1985.

EEG-31 Ramey, Dan, Chemistry of the Rustler Fluids, July 1985.

EEG-32 Chaturvedi, Lokesh and James K. Channell, The Rustler Formation as a Transport Medium for Contaminated Groundwater, December 1985. 


\section{LIST OF EEG REPORTS (CONTINUED)}

EEG-33 Channell, James K., John C. Rodgers, Robert H. Neill, Adequacy of TRUPACT-I Design for Transporting Contact-Handled Transuranic Wastes to WIPP, June 1986.

EEG-34 Chaturvedi, Lokesh, (ed.), The Rustler Formation at the WIPP Site, Report of a Workshop on the Geology and Hydrology of the Rustler Formation as it Relates to the WIPP Project, February 1987.

EEG-35 Chapman, Jenny B., Stable Isotopes in Southeastern New Mexico Groundwater: Implications for Dating Recharge in the WIPP Area, October 1986.

EEG-36 Lowenstein, Tim K., Post Burial Alteration of the Permian Rustler Formation Evaporites, WIPP Site, New Mexico, April 1987.

EEG-37 Rodgers, John C., Exhaust Stack Monitoring Issues at the Waste Isolation Pilot Plant, November 1987.

EEG-38 Rodgers, John C. and Jim W. Kenney, A Critical Assessment of Continuous Air Monitoring Systems at the Waste Isolation Pilot Plant, March 1988.

EEG-39 Chapman, Jenny B., Chemical and Radiochemical Characteristics of Groundwater in the Culebra Dolomite, Southeastern New Mexico, March 1988.

EEG-40 Review of the Final Safety Analyses Report (Draft), DOE Waste Isolation Pilot Plant. December 1988, May 1989.

EEG-41 Review of the Draft Supplement Environmental Impact Statement, DOE Waste Isolation Pilot Plant, July 1989.

EEG-42 Chaturvedi, Lokesh, Evaluation of the DOE Plans for Radioactive Experiments and Operational Demonstration at WIPP, September 1989.

EEG-43 Kenney, Jim W., John Rodgers, Jenny Chapman, Kevin Shenk, Preoperational Radiation Surveillance of the WIPP Project by EEG 1985-1988, January 1990.

EEG-44 Greenfield, Moses A., Probabilities of a Catastrophic Waste Hoist Accident at the Waste Isolation Pilot Plant, January 1990.

EEG-45 Silva, Matthew K., Preliminary Investigation into the Explosion Potential of Volatile Organic Compounds in WIPP CH-TRU Waste, June 1990.

EEG-46 Gallegos, Anthony F. and James K. Channell, Risk Analysis of the Transport of Contact Handled Transuranic (CH-TRU) Wastes to WIPP Along Selected Highway Routes in New Mexico Using RADTRAN IV, August 1990.

EEG-47 Kenney, Jim W. and Sally C. Ballard, Preoperational Radiation Surveillance of the WIPP Project bv EEG During 1989, December 1990.

EEG-48 Silva, Matthew, An Assessment of the Flammability and Explosion Potential of Transuranic Waste, June 1991. 


\section{LIST OF EEG REPORTS (CONTINUED)}

EEG-49 Kenney, Jim, Preoperational Radiation Surveillance of the WIPP Project by EEG During 1990, November 1991.

EEG-50 Silva, Matthew K. and James K. Channell, Implications of Oil and Gas Leases at the WIPP on Compliance with EPA TRU Waste Disposal Standards, June 1992.

EEG-51 Kenney, Jim W., Preoperational Radiation Surveillance of the WIPP Project by EEG During 1991, October 1992.

EEG-52 Bartlett, William T., An Evaluation of Air Effluent and Workplace Radioactivity Monitoring at the Waste Isolation Pilot Plant, February 1993.

EEG-53 Greenfield, Moses A. and Thomas J. Sargent, A Probabilistic Analysis of a Catastrophic Transuranic Waste Hoist Accident at the WIPP, June 1993.

EEG-54 Kenney, Jim W., Preoperational Radiation Surveillance of the WIPP Project by EEG During 1992, February 1994.

EEG-55 Silva, Matthew K., Implications of the Presence of Petroleum Resources on the Integrity of the WIPP, June 1994.

EEG-56 Silva, Matthew K. and Robert H. Neill, Unresolved Issues for the Disposal of RemoteHandled Transuranic Waste in the Waste isolation Pilot Plant, September 1994.

EEG-57 Lee, William W.-L, Lokesh Chaturvedi, Matthew K. Silva, Ruth Weiner, and Robert H. Neill, An Appraisal of the 1992 Preliminary Performance Assessment for the Waste Isolation Pilot Plant, September 1994.

EEG-58 Kenney, Jim W., Paula S. Downes, Donald H. Gray, Sally C. Ballard, Radionuclide Baseline in Soil Near Project Gnome and the Waste Isolation Pilot Plant, June 1995.

EEG-59 Greenfield, Moses A. and Thomas J. Sargent, An Analysis of the Annual Probability of Failure of the Waste Hoist Brake System at the Waste Isolation Pilot Plant (WIPP), November 1995.

EEG-60 Bartlett, William T. and Ben A. Walker, The Influence of Salt Aerosol on Alpha Radiation Detection by WIPP Continuous Air Monitors, January 1996.

EEG-61 Neill, Robert, Lokesh Chaturvedi, William W.-L. Lee, Thomas M. Clemo, Matthew K. Silva, Jim W. Kenney, William T. Bartlett, and Ben A. Walker, Review of the WIPP Draft Application to Show Compliance with EPA Transuranic Waste Disposal Standards, March 1996.

EEG-62 Silva, Matthew K., Fluid Injection for Salt Water Disposal and Enhanced Oil Recovery as a Potential Problem for the WIPP: Proceedings of a June 1995 Workshop and Analysis, August 1996.

EEG-63 Maleki, Hamid and Lokesh Chaturvedi, Stability Evaluation of the Panel 1 Rooms and the E140 Drift at WIPP, August 1996. 


\section{LIST OF EEG REPORTS (CONTINUED)}

EEG-64 Neill, Robert H., James K. Channell, Peter Spiegler, Lokesh Chaturvedi, Review of the Draft Supplement to the WIPP Environmental Impact Statement. DOE/EIS-0026-S-2, April 1997.

EEG-65 Greenfield, Moses A. and Thomas J. Sargent, Probability of Failure of the Waste Hoist Brake System at the Waste Isolation Pilot Plant(WIPP), January 1998.

EEG-66 Channell, James K. and Robert H. Neill, Individual Radiation Doses From Transuranic Waste Brought to the Surface by Human Intrusion at the WIPP, February 1998.

EEG-67 Kenney, Jim W., Donald H. Gray, and Sally C. Ballard, Preoperational Radiation Surveillance of the WIPP Project by EEG During 1993 Though 1995, March 1998.

EEG-68 Neill, Robert H., Lokesh Chaturvedi, Dale F. Rucker, Matthew K. Silva, Ben A. Walker, James K. Channell, Thomas M. Clemo, Evaluation of the WIPP Project's Compliance with the EPA Radiation Protection Standards for Disposal of Transuranic Waste, March 1998.

EEG-69 Rucker, Dale, Sensitivity Analysis of Performance Parameters Used In Modeling the Waste Isolation Pilot Plant, May 1998.

EEG-70 Bartlett, William T. and Jim W. Kenney, EEG Observations of the March 1998 WIPP Operational Readiness Review Audit, May 1998.

EEG-71 Maleki, Hamid, Mine Stability Evaluation of Panel 1 During Waste Emplacement Operations at WIPP, July 1998.

EEG-72 Channell, James K. and Robert H. Neill, A Comparison of the Risks from the Hazardous Waste and Radioactive Waste Portions of the WIPP Inventory, July 1999.

EEG-73 Kenney, Jim W., Donald H. Gray, Sally C. Ballard, and Lokesh Chaturvedi, Preoperational Radiation Surveillance of the WIPP Project by EEG from 1996 - 1998, October 1999.

EEG-74 Greenfield, Moses A. and Thomas J. Sargent, Probability of Failure of the TRUDOCK Crane System at the Waste Isolation Pilot Plant (WIPP), May 2000. 